\title{
The transport of chemical components in homogeneous snowpacks on Urumqi Glacier No. 1, eastern Tianshan Mountains, Central Asia
}

\author{
YOU Xiaoni ${ }^{12^{*}}$, LI Zhongqin ${ }^{1}$, Ross EDWARDS ${ }^{3}$, WANG Lixia $^{2}$ \\ ${ }^{1}$ Key Laboratory of Cryosphere and Environment/Tianshan Glaciological Station/Laboratory of Ice Core and Cold Regions \\ Environment, Cold and Arid Regions Environmental and Engineering Research Institute, Chinese Academy of Sciences, \\ Lanzhou 730000, China; \\ ${ }^{2}$ Tianshui Normal University, Tianshui 741001, China; \\ ${ }^{3}$ Imaging and Applied Physics, Curtin University of Technology, Bentley WA 6102, Australia
}

\begin{abstract}
Chemical records from alpine ice cores provide an invaluable source of paleoclimatic and environmental information. Not only the atmospheric chemical composition but also depositional and post-depositional processes are recorded within snow/firn strata. To interpret the environmental and climatic significance of ice core records, we studied the variability of glacier snowpack chemistry by investigating homogeneous snowpacks from October 2003 to September 2006 on Urumqi Glacier No. 1 in eastern Tianshan Mountains, Central Asia. Principle Component Analysis of ionic species in dry and wet seasons revealed the impact of meltwater in redistributing ions in the snowpacks. The $1^{\text {st }}, 2^{\text {nd }}$ and $3^{\text {rd }}$ principle components for dry seasons differ significantly, reflecting complex associations between depositional or/and post-depositional processes. The variability trend of ionic concentrations during the wet seasons was found to fit a Gauss Function with significant parameters. The elution factor revealed that more than half of ions are leached out during the wet seasons. Differences with respect to ion snowpack mobility were found. Of the ions studied $\mathrm{SO}_{4}{ }^{2-}$ was the most mobile and $\mathrm{Mg}^{2+}$ the least mobile. A threshold relationship between air temperatures and the elution process was investigated over the study period. The results indicate that the strong melt /ablation processes and iconic redistribution occur at a threshold air temperature of $0^{\circ} \mathrm{C}$. The study found that surface melt on the snowpacks is the main factor causing the alteration of the snowpack chemistry. Rainfall also has an impact on the chemistry but plays a less significant role than the surface melt.
\end{abstract}

Keywords: Urumqi Glacier No. 1; snowpack; meltwater; air temperature; precipitation

Citation: YOU Xiaoni, LI Zhongqin, Ross EDWARDS, WANG Lixia. 2015. The transport of chemical components in homogeneous snowpacks on Urumqi Glacier No. 1, eastern Tianshan Mountains, Central Asia. Journal of Arid Land, 7(5): 612-622. doi: 10.1007/s40333-015-0131-z

Ice core records have proven to be an invaluable source of information for understanding past climatic and environmental conditions. However, they record not only the chemical composition of the atmosphere and deposition processes, but also post-depositional processes acting in and on snowpacks. Snowpack post-depositional processes include diffusion (Sigg and Neftel, 1991), sublimation (Wagnon et al., 1999), snowdrift and chemical reactions between impurities (Woff et al., 1998). In warmer conditions, wet processes are the dominant cause of snowpack chemical alteration and the primary challenge with regards to ice core record interpretation (Sigg and Neftel, 1991; Wagnon et al., 1999). Wet processes occur principally in temperate glaciers at temperatures near the freezing point. The impact of meltwater on the original chemical components of snowpacks has been the subject of a number of studies (Johannessen and Henriksen, 1978; Brimblecombe, 1985; Brimblecombe et al., 1987; Bales et al., 1989; Hewitt et al., 1989; Davis, 1991; Tranter, 1991), especially the ionic redistribution, transport and preferential elution with seasonal

*Corresponding author: YOU Xiaoni (E-mail: yxn_818@yeah.net)

Received 2014-09-29; revised 2015-03-13; accepted 2015-05-18

(C) Xinjiang Institute of Ecology and Geography, Chinese Academy of Sciences, Science Press and Springer-Verlag Berlin Heidelberg 2015 
melting (Johannessen and Henriksen, 1978; Brimblecombe, 1985; Goto-Azuma et al., 1994; Harrington et al., 1996; Eichler et al., 2001; Lee et al., 2008a; Bernhardt et al., 2012). Advances in both analytical and mathematical techniques have resulted in a greater capacity for modeling the ionic evolution of snowpacks (Harrington and Bales, 1998; Moore et al., 2005; Lee et al., 2008b; Moore and Grinsted, 2009; Meyer and Wania, 2011).

Investigations of wet processes on snowpack chemistry species and temperature conditions are needed to interpret ice core records from temperate glaciers. Here we present results from snow samples collected from Urumqi Glacier No. 1, eastern Tianshan Mountains during October 2003-September 2006.

\section{Materials and methods}

\subsection{Sampling site}

We analyzed successive snowpacks on Urumqi Glacier No.1 $\left(43^{\circ} 06^{\prime} \mathrm{N}, 86^{\circ} 49^{\prime} \mathrm{E}\right)$, located at the headwaters of Urumqi River in Tianshan Mountains, Central Asia. The glacier has a continental climate, dominated by the prevailing westerly jet stream (Wang and Zhang, 1985; Li et al., 2003). The sampling site was situated on the glacier at $4,130 \mathrm{~m}$ asl. During the study period the annual mean air temperature was $-8.9^{\circ} \mathrm{C}$ and the annual precipitation was $493 \mathrm{~mm}$. Most of the precipitation $(>90 \%)$ to the site occurs from April to October (wet seasons), with only small amounts falling in the winter (dry seasons; Aizen et al., 2001). A sample site was chosen with shadowing by the surrounding mountain ridges, to limit direct exposure to sunshine. Snowpit investigations found that the base of the snowpacks at this site is composed of superimposed ice which is typically formed in the glacial percolation zone or superimposed ice zone (Wang et al., 2006; Li et al., 2007). This ice is clear and impermeable, with spherical bubbles of 1-5 $\mathrm{mm}$ diameter. During the study, we tracked the transformation of the snowpacks and found that the conversion of snow to superimposed ice took approximately 41-47 months (You et al., 2005).

\subsection{Sample collection and analysis}

Both the surface snow and snowpack samples were collected weekly at the sampling site. Surface snow samples were recovered from the upper centimeter skin of snow $(1-3 \mathrm{~cm})$ for sure that fresh snow could be obtained as more as possible to investigate the chemical seasonality in precipitation and dry deposition. Snowpits were dug down until to the superimposed ice (Wang et al., 2006). Snowpack samples were collected from the top to the bottom of the pit at $10 \mathrm{~cm}$ increments for acquiring the mean concentration values of snow and firn. The pit was refilled after each sampling process to make sure that the snow was not polluted. The wall was then cut back by at least 50 $\mathrm{cm}$ before the next round of sample collection. Over the duration of the sampling campaign, in situ air temperature was continuously observed using a thermometer screen near the sampling site.

Strict procedures were followed during sampling and transportation to prevent contamination, including using disposable polyethylene gloves, oronasal masks, and precleaned polyethylene sample containers. All samples were transported frozen to the Key Laboratory of Cryosphere and Environment, Cold and Arid Regions Environmental and Engineering Research Institute, Chinese Academy of Sciences. Blanks were made at each step in the process to ensure that the cumulative contamination remained below the baseline of each measured chemical species ( $\mathrm{Li}$ et al., 2006). Samples were analyzed for major chemical ions (including $\mathrm{Na}^{+}, \mathrm{K}^{+}, \mathrm{Ca}^{2+}, \mathrm{Mg}^{2+}, \mathrm{NH}_{4}^{+}, \mathrm{Cl}^{-}, \mathrm{SO}_{4}{ }^{2-}$ and $\mathrm{NO}_{3}{ }^{-}$) by ion chromatography (Dionex DX-320) with a CS12A separation column (Zhao and Li, 2004). Detection limit $(\mathrm{mg} / \mathrm{L})$ of these ions are $0.0006\left(\mathrm{Na}^{+}\right)$, $0.0009\left(\mathrm{~K}^{+}\right), 0.00075\left(\mathrm{Ca}^{2+}\right), 0.0008\left(\mathrm{Mg}^{2+}\right), 0.0010$ $\left(\mathrm{NH}_{4}{ }^{+}\right), 0.0006\left(\mathrm{Cl}^{-}\right), 0.00085\left(\mathrm{SO}_{4}{ }^{2-}\right)$ and 0.00065 $\left(\mathrm{NO}_{3}{ }^{-}\right)$respectively with precision range from $2 \%-12 \%$.

In addition, simple observations of drifting snow were carried out. Drifting snow generally appeared as wind-board on Urumqi Glacier No. 1. It was close-grained and harder than snow, and covered on the top of snow at the sampling site. We measured the thickness of the wind-board every time when we sampled in winter.

\subsection{Data and methods}

Data for the study covered a 3-year period from October 2003 to September 2006 and included major 
ionic concentrations in the snowpacks, diurnal mean air temperatures and precipitation. The snow dataset comprised 3,199 snowpit samples (from 143 snowpits) and 143 surface snow samples. Principal Component Analysis (PCA) was used to investigate sources of chemical species in surface snow, similar to a number of other studies (Moore et al., 2005; Li et al., 2006; Zhao et al., 2006; Li et al., 2007; Moore and Grinsted, 2009). We used PCA to investigate the major ionic chemistry. It was used instead of other multivariate methods due to its relative simplicity with respect to separating linearly uncorrelated components. The PCA analysis results were compared with a range of site-specific indices derived from climate and other site characteristics such as meltwater (Moore and Grinsted, 2009). Prior to PCA, ionic concentrations were $\log$ transformed and normalized to zero mean and unit variance.

\section{Results and discussion}

\subsection{Post-depositional processes versus ion source effects}

Based on the amount of precipitation, we can present the ionic concentration data in two different seasons during one year, with approximately the same number of samples in each one: dry season ranges from 1 October to 31 March and wet season ranges from 1 April to 30 September. Three dry seasons and three wet seasons are presented in total. In situ measurement showed that the average precipitation was $46 \mathrm{~mm}$ in dry seasons and $447 \mathrm{~mm}$ in wet seasons; the diurnal mean temperature was $-15.7^{\circ} \mathrm{C}$ and $-2.5^{\circ} \mathrm{C}$, respectively.

We applied PCA in each season from October 2003 till September 2006, each involving 8 variables representing the standardized values of each log ionic concentration in the snowpacks. In wet seasons, the first component accounts for most of the variance in the dataset $(>70 \%)$. The second component accounts for $5 \%-10 \%$, the third component contribute about $3 \%-8 \%$ and the others less than $9 \%$. The first three components account for more than $90 \%$ of the variance (Table 1). The first component is loaded by all the ionic species, which suggests that all the ionic concentrations are transformed by meltwater percolation dominantly. The second component has higher loads for magnesium and potassium, which is probably aroused by the effects of independent sources. Differently, in dry seasons, the first component accounts for $40 \%-60 \%$ of the variance and the first three components account for only $79 \%$ in average. This suggests that the ionic species have different sources and/or co-location in the snowpacks.

Association between ionic species in the snowpacks may be due to two different processes: co-variation of ions in the precipitation, or post-depositional movement and preferential relocation of ions in different ice faces (Moore et al., 2005). To illustrate some of these differences we plotted the eigenvectors of component 1 (F1) against those for component 2 (F2) for the wet seasons and dry seasons (Fig. 1). Relative groupings for each season highlight the different behavior of ions

Table 1 Total variance explained by the first three components for chemical elements in the snowpacks during the dry seasons and the wet seasons from October 2003 to September 2006

\begin{tabular}{|c|c|c|c|c|c|c|c|c|c|}
\hline \multirow{3}{*}{ Time period } & \multicolumn{9}{|c|}{ Total variance explained } \\
\hline & \multicolumn{3}{|c|}{ Component 1} & \multicolumn{3}{|c|}{ Component 2} & \multicolumn{3}{|c|}{ Component 3} \\
\hline & $\begin{array}{l}\text { Total Vari- } \\
\text { ance }\end{array}$ & $\begin{array}{c}\text { Variance } \\
(\%)\end{array}$ & $\begin{array}{c}\text { Cumulation } \\
(\%)\end{array}$ & $\begin{array}{l}\text { Total Vari- } \\
\text { ance }\end{array}$ & $\begin{array}{c}\text { Variance } \\
(\%)\end{array}$ & $\begin{array}{c}\text { Cumulation } \\
(\%)\end{array}$ & $\begin{array}{l}\text { Total Vari- } \\
\text { ance }\end{array}$ & $\begin{array}{c}\text { Variance } \\
(\%)\end{array}$ & $\begin{array}{c}\text { Cumulation } \\
(\%)\end{array}$ \\
\hline \multicolumn{10}{|l|}{ Dry season } \\
\hline Oct 2003-Mar 2004 & 3.267 & 40.840 & 40.840 & 1.468 & 18.349 & 59.189 & 1.182 & 14.772 & 73.961 \\
\hline Oct 2004-Mar 2005 & 3.285 & 41.066 & 41.066 & 1.922 & 24.026 & 65.092 & 1.025 & 12.818 & 77.910 \\
\hline Oct 2005- Mar 2006 & 5.101 & 63.769 & 63.769 & 0.927 & 11.584 & 75.352 & 0.742 & 9.270 & 84.622 \\
\hline \multicolumn{10}{|l|}{ Wet season } \\
\hline Apr 2004-Sep 2004 & 5.994 & 74.927 & 74.927 & 0.753 & 9.410 & 84.337 & 0.627 & 7.835 & 92.172 \\
\hline Apr 2005-Sep 2005 & 7.089 & 88.612 & 88.612 & 0.400 & 4.998 & 93.611 & 0.199 & 2.483 & 96.094 \\
\hline Apr 2006-Sep 2006 & 6.145 & 76.811 & 76.811 & 0.743 & 9.291 & 86.102 & 0.463 & 5.785 & 91.887 \\
\hline
\end{tabular}



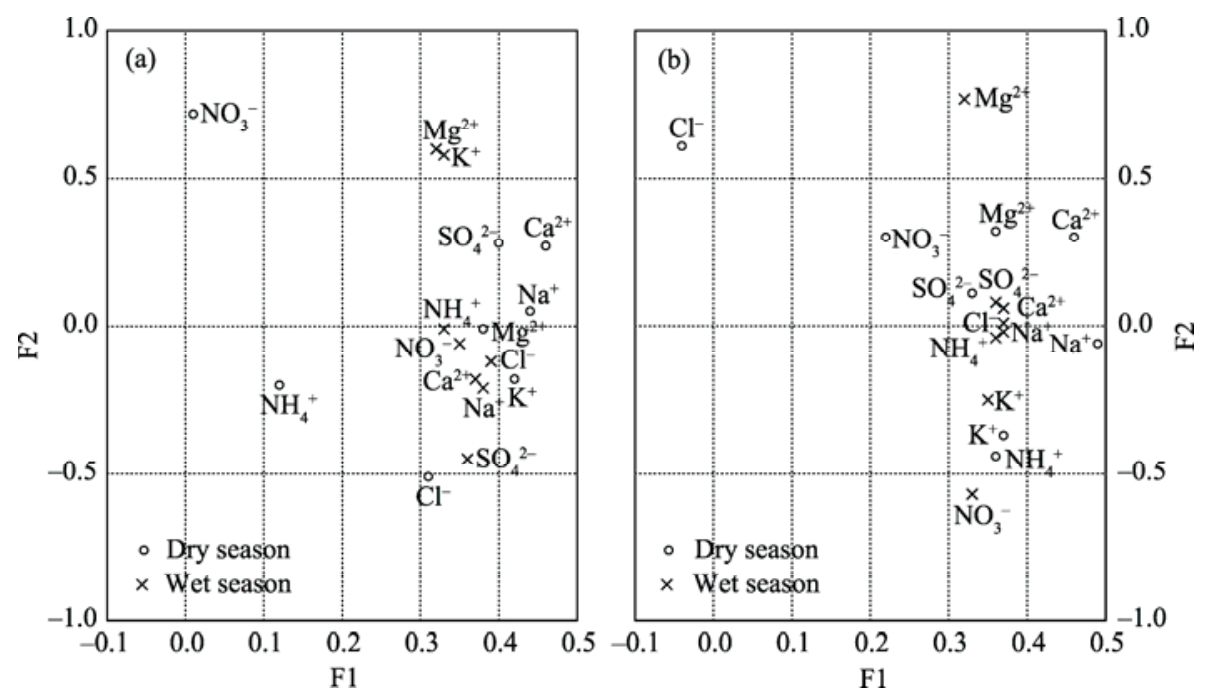

Fig. 1 The eigenvectors of component 1 (F1) and component 2 (F2) for October 2003-March 2004 (o) and April 2004-September 2004 (x) (a); the eigenvectors of component 1 (F1) and component 2 (F2) for October 2004-March 2005 (o) and April $2005-$ September 2005 (x) (b)

for depositional or/and post-depositional processes. Figure 1a shows that, in the 2003-2004 wet season, the clustering for $\mathrm{NH}_{4}{ }^{+}, \mathrm{Ca}^{2+}, \mathrm{Na}^{+}, \mathrm{NO}_{3}{ }^{-}$and $\mathrm{Cl}^{-}$had a more positive $\mathrm{F} 2$ than that for $\mathrm{Mg}^{2+}$ and $\mathrm{K}^{+}$, while the clustering for $\mathrm{SO}_{4}{ }^{2-}$ had a relatively negative $\mathrm{F} 2$. In the 2003-2004 dry season, ions were scattered across the F1/F2 plot, which suggests multiple ion sources and/or post-depositional processes. The scatter is especially large for $\mathrm{Cl}^{-}, \mathrm{NO}_{3}{ }^{-}$and $\mathrm{NH}_{4}{ }^{+}$. Less variability was found for the 2004-2005 wet season. Figure $1 \mathrm{~b}$ shows that $\mathrm{NH}_{4}^{+}, \mathrm{Ca}^{2+}, \mathrm{Na}^{+}, \mathrm{SO}_{4}{ }^{2-}$ and $\mathrm{Cl}^{-}$ cluster, which implies stronger effects from meltwater on ion elution. $\mathrm{Mg}^{2+}, \mathrm{NO}_{3}^{-}$and $\mathrm{K}^{+}$are scattered during this period. In the dry season (October 2004-March 2005), the ion association is similar with those of 2003-2004, with the exception of $\mathrm{Cl}^{-}$and $\mathrm{NH}_{4}{ }^{+}$that swap their relative positions. The difference between these ions may reflect differences in deposition and post-depositional processes between the two dry season periods.

Several processes alter ionic concentrations in the snowpacks. These include wet and dry deposition processes and post-depositional processes including snowdrift, sublimation, firn densification and meltwater percolation. For most temperate glaciers, meltwater may smoothen variability produced by other processes. In this study, the wet season eigenvectors suggest a smoothing on the ionic variability indicative of meltwater (Table 1; Fig. 1). The separation of $\mathrm{Mg}^{2+}$ and $\mathrm{K}^{+}$(Fig. 1b) likely results from variability in precipitation concentrations. Previous studies have found $\mathrm{Mg}^{2+}$ to be a tracer of long-distance transport, which is mainly deposited by precipitation in August ( $\mathrm{Li}$ et al., 2006; You and $\mathrm{Li}, 2012$ ). Potential $\mathrm{Mg}^{2+}$ sources are mineral dust and evaporated aerosols entrained by the air masses that bring moisture to the region. Snowpack $\mathrm{K}^{+}$has been found to be derived from local rocks and glacial sediments (Luo, 1983; Williams et al., 1991; Hou and Qin, 2002). Both $\mathrm{Mg}^{2+}$ and $\mathrm{K}^{+}$were found to be relatively immobile in the snowpacks compared to the other ionic species. Their clustering in the snowpacks in the 2003-2004 wet season (Fig. 1a) is likely the result of their resistance to transport.

Wet-season precipitation accounts for approximately $90 \%$ of the annual precipitation, which can bring terrestrial impurities to the glacier surface. During dry seasons, meltwater is nil or very little. Precipitation is also infrequent. All of the major post-depositional processes potentially facilitate the alteration of the ionic concentrations: such as snowdrift, sublimation and dry deposition (Bernhardt et al., 2012). Studies have shown that most ions (except for $\mathrm{NH}_{4}{ }^{+}$) can be enriched in surface snow by sublimation; mineral dust components such as $\mathrm{Ca}^{2+}, \mathrm{Mg}^{2+}$ and $\mathrm{Na}^{+}$ can also be enriched by dry deposition (Ginot et al., 2001; Schotterer and Ginot, 2004); snowdrift that can 
scavenge particles from the lower levels of the troposphere may lead to an increase in $\mathrm{NO}_{3}{ }^{-}$concentration in snow (Wolff et al., 1998). Moreover, initial position of species in the original snow crystals also effects the ionic concentrations in the snowpacks. For example, $\mathrm{Cl}^{-}$is considered to be in the center of a snow crystal (Tsiouris et al., 1985) and should be less mobile compared to those species being attached to the surface of a snow crystal. As for $\mathrm{NH}_{4}{ }^{+}$, it is easily incorporated within the ice lattice, and has high solid-phase mobility within the ice lattice (Eichler et al., 2001). Therefore, the variation of ionic concentration in the snowpacks shows distinctive characteristics.

To explore how atmosphere conditions influence chemical records in the snowpacks, we investigated the relationship between the ionic concentrations and meteorology.

\subsection{Characteristics of ionic concentrations with snow melting}

2.2.1 Variation of ionic concentrations in wet seasons

The wet season of April 2005-September 2005 was chosen to investigate the variation of ionic concentrations in the snowpacks (Fig. 2). We drew the scatter diagrams of each chemical ion against date. Curve fitting was made with Gauss Function as follow:

$$
y=y_{\mathrm{o}}+\frac{A}{W \sqrt{\pi / 2}} \mathrm{e}^{-2 \frac{\left(x-x_{\mathrm{c}}\right)^{2}}{W^{2}}} .
$$

Where $y_{0}$ stands for the offset of the fitting curve, $W$ and $A$ are the width and area of the curve, respectively, $x_{\mathrm{c}}$ is the center point of the curve. Here we try to explain the leaching process with the fitting function parameters. Parameter $x_{\mathrm{c}}$ suggests a point on which ionic concentration reaches to the minimum. $\mathrm{For}^{-}$, $\mathrm{Na}^{+}, \mathrm{Mg}^{2+}$ and $\mathrm{Ca}^{2+}, x_{\mathrm{c}}$ values are identical, and they reach the minimum at the middle of the August simultaneously. The $x_{\mathrm{c}}$ values of $\mathrm{SO}_{4}{ }^{2-}, \mathrm{NH}_{4}{ }^{+}$and $\mathrm{K}^{+}$are the same, and they experienced the most losses at the early of the August. The concentrations of $\mathrm{NO}_{3}{ }^{-}$fall down to the lowest point at the beginning of August with the smallest $x_{\mathrm{c}}$ value. It could be concluded that $\mathrm{NO}_{3}{ }^{-}$is the easiest to be leached out, and $\mathrm{Cl}^{-}, \mathrm{Na}^{+}$, $\mathrm{Mg}^{2+}$ and $\mathrm{Ca}^{2+}$ are relatively stable compared to other ionic species (Table 2). Parameter $y_{0}$ indicates that each ion starts to leach with different concentrations, for instance $\mathrm{Ca}^{2+}$ is the highest with $y_{\mathrm{o}}$ of 1,226 and $\mathrm{K}^{+}$is the lowest with $y_{0}$ of 42 . The larger $W$ means are, the wider the trough of the fitting curve is, which suggests that ions begin to be washed out much earlier and could be regarded as an indicator of preferential elution (detailed in section 2.2.2). Function parameters for the eight ions and total ions (total ions means the sum of all the ions.) are given in Table 2 .

All the curves are fitted well by Gauss Function, especially those for $\mathrm{Ca}^{2+}, \mathrm{Na}^{+}, \mathrm{NO}_{3}{ }^{-}, \mathrm{SO}_{4}{ }^{2-}$ and $\mathrm{Cl}^{-}$, with correlation coefficients $\left(R^{2}\right)$ of $0.89,0.84,0.82$, 0.79 and 0.79 , respectively ( $n=26, P<0.01$; Table 2 ). The correlations of the fitting curves for $\mathrm{Mg}^{2+}$ and $\mathrm{K}^{+}$ are lower, with $R^{2}$ value of 0.64 and 0.71 , respectively. During the wet season, ionic concentrations decreased at first and reached to the minimum in around the middle of August. Then, they went up dramatically, and kept relatively stable at the beginning of the dry season (Fig. 2). The ionic concentrations are characterized by quite scattered dots before strong elution, illustrating that there were frequent alterations. The

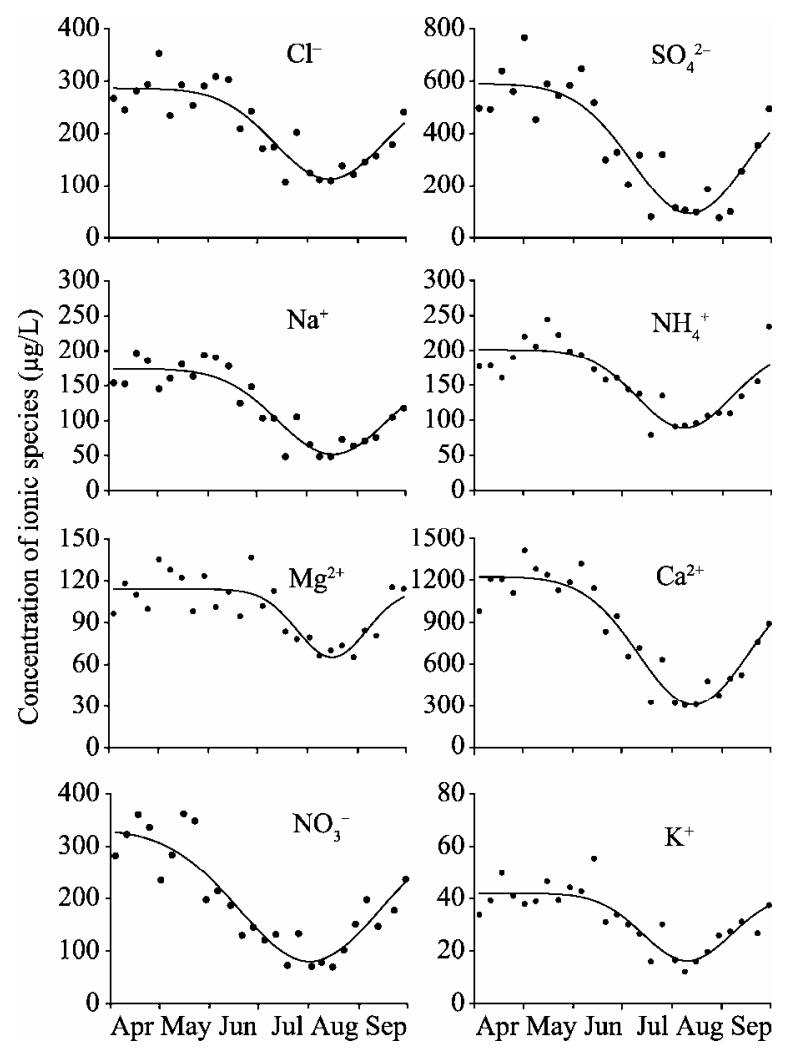

Fig. 2 Concentration variations of ionic species in the snowpacks during the wet season of April 2005-September 2005; solid lines are fitting curves. 
Table 2 Parameters of fitting function for major ionic species and total ions

\begin{tabular}{|c|c|c|c|c|c|c|}
\hline \multirow{2}{*}{ Ion } & \multicolumn{5}{|c|}{ Parameter } & \multirow{2}{*}{$R^{2}$} \\
\hline & $y_{\mathrm{o}}$ & $A$ & $w$ & $x_{\mathrm{c}}$ & $y_{\mathrm{c}}$ & \\
\hline $\mathrm{Cl}^{-}$ & 286 & $-14,522$ & 67 & $2.45360 \mathrm{E} 6$ & 113 & 0.79 \\
\hline $\mathrm{SO}_{4}^{2-}$ & 590 & $-43,997$ & 71 & 2.45359E6 & 95 & 0.79 \\
\hline $\mathrm{NO}_{3}^{-}$ & 333 & $-27,813$ & 88 & $2.45358 \mathrm{E} 6$ & 81 & 0.82 \\
\hline $\mathrm{Na}^{+}$ & 174 & $-10,332$ & 68 & $2.45360 \mathrm{E} 6$ & 53 & 0.84 \\
\hline $\mathrm{NH}_{4}^{+}$ & 201 & $-8,247$ & 59 & $2.45359 \mathrm{E} 6$ & 89 & 0.75 \\
\hline $\mathrm{K}^{+}$ & 42 & $-1,762$ & 55 & $2.45359 \mathrm{E} 6$ & 16 & 0.71 \\
\hline $\mathrm{Mg}^{2+}$ & 114 & $-2,611$ & 43 & $2.45360 \mathrm{E} 6$ & 66 & 0.64 \\
\hline $\mathrm{Ca}^{2+}$ & 1,226 & $-77,760$ & 68 & $2.45360 \mathrm{E} 6$ & 313 & 0.89 \\
\hline Total ions & 2,939 & $-181,280$ & 69 & $2.45359 \mathrm{E} 6$ & 842 & 0.89 \\
\hline
\end{tabular}

Note: the meanings of $y_{\mathrm{o}}, A, w, x_{\mathrm{c}}, y_{\mathrm{c}}$ are the same as in Eq. 1 .

alterations apparently resulted from dust-storm derived mineral aerosols entrained in precipitation due to increasing precipitation and frequent Asian dust-storm events in this season (Fig. 3). In around June 2005, the ionic concentrations are found to be controlled mainly by the elution process. In 2005 , the precipitation was $464.6 \mathrm{~mm}$ in the wet season, accounting for $85 \%$ of the total annual precipitation. Positive accumulated temperature went up to $113.2^{\circ} \mathrm{C}$. Concurrent with the precipitation, ablation also occurred during the same period. Therefore, the ionic information from precipitation was mostly lost.

We compared the relationship among the total ionic concentrations and positive accumulated temperatures and precipitations in wet seasons from 2003 till 2006 (Fig. 3), and found that ionic concentration curves

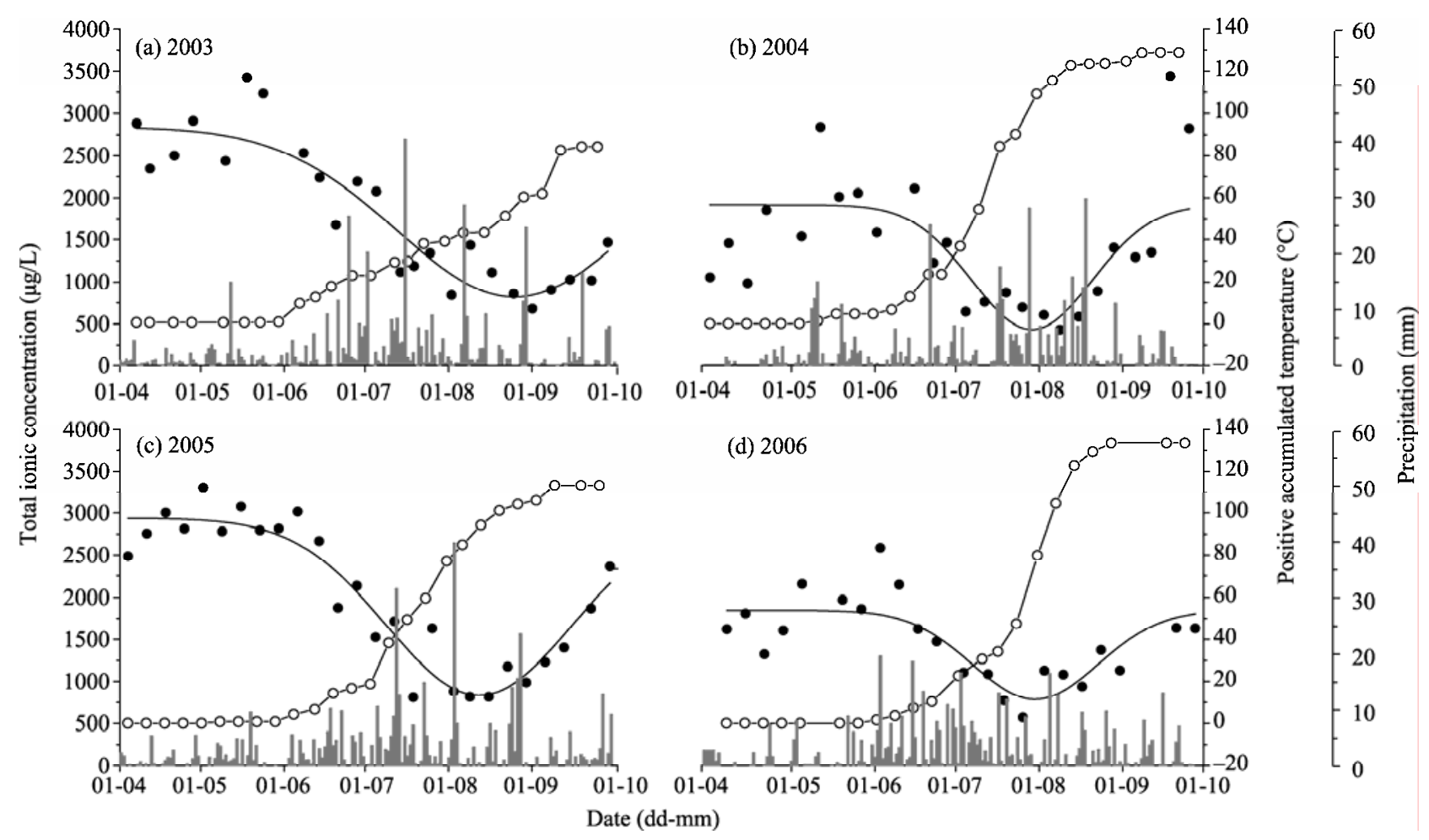

Fig. 3 Total ionic concentrations in the snowpacks, positive accumulated temperatures and precipitations during the wet seasons of 2003-2006. Black dots are total ionic concentrations; solid lines are their fitting curves; circles are positive accumulated temperatures; grey columns are precipitations. 
display similar variations. The correlations of the fitting curves are remarkable in 2003 and 2005 with $R^{2}$ values of 0.83 and 0.89 , respectively; weak correlations are found in 2004 and 2006 with $R^{2}$ values of 0.40 and 0.60 , respectively. Obviously, precipitation produced little effects on ionic concentrations in the snowpacks during the wet seasons. The concentrations fall down to the lowest values even though major precipitation events happened. However, precipitations appeared at the ends of the wet seasons may contribute to the increase of ionic contents. Temperature plays a significant role in ionic concentration variations. Ionic concentrations drop rapidly once diurnal air temperatures are more than $0^{\circ} \mathrm{C}$. However, ionic concentrations began to increase even though the air temperatures still kept in higher levels at the ends of the wet seasons. The reason is that the ice and snow temperatures had already went down and the amount of meltwater was on decrease so that chemical components from precipitation and aerosol transported by wind could be conserved well (Li et al., 2006; You and $\mathrm{Li}, 2012$ ). It is concluded that merely the precipitation occurred at the ends of the wet seasons (around from the middle of August to the end of September) was preserved in the glacier.

\subsubsection{Elution sequence}

From the fitting parameter " $W$ " we determined the elution sequence. A higher value of " $W$ " means more efficient elution. The elution sequence was as follows: $\mathrm{NO}_{3}{ }^{-}>\mathrm{SO}_{4}{ }^{2-}>\mathrm{Ca}^{2+} \sim \mathrm{Na}^{+}>\mathrm{Cl}^{-}>\mathrm{NH}_{4}^{+}>\mathrm{K}^{+}>\mathrm{Mg}^{2+}$. The sequence was slightly different from reported by previous studies by $\mathrm{Li}$ et al. (2006), who determined the elution order as $\mathrm{SO}_{4}{ }^{2-}>\mathrm{Ca}^{2+}>\mathrm{Na}^{+}>\mathrm{NO}_{3}{ }^{-}>\mathrm{Cl}^{-}>\mathrm{K}^{+}>$ $\mathrm{Mg}^{2+}>\mathrm{NH}_{4}{ }^{+}$. The sequence from this study was based on the comparison of ion concentration ratios. Studies from other locations have found different sequences. A field study described in Brimblecombe et al. (1987) observed an elution order of $\mathrm{SO}_{4}{ }^{2-}>\mathrm{NO}_{3}{ }^{-}>\mathrm{NH}_{4}{ }^{+}>\mathrm{K}^{+}>\mathrm{Ca}^{2+}>$ $\mathrm{Mg}^{2+}>\mathrm{Na}^{+}>\mathrm{Cl}^{-}$. From laboratory experiments, Hewitt et al. (1989) determined an elution sequence of $\mathrm{SO}_{4}{ }^{2-}>\mathrm{Ca}^{2+}>\mathrm{Mg}^{2+}>\mathrm{K}^{+}>\mathrm{Na}^{+}>\mathrm{NO}_{3}{ }^{-}>\mathrm{Cl}^{-}$.
As described in various field and laboratory studies, ions are leached out of snow and firn with different efficiencies (Brimblecombe et al., 1987; Tranter et al., 1992; Eichler et al., 2001; Iizuka et al., 2002). However, differences in the elution sequence may be caused by differences in the composition of the natural snowpacks or the experimental conditions in the laboratory (Tsiouris et al., 1985). Snow metamorphism, re-emission of species from the snowpacks and the solubility of ionic species in firn may also influence the order of elution (Eichler et al., 2001). The elution sequence, hence, may be varied both temporally and spatially. Studies from other regions in Central Asia are needed to determine whether the observed elution sequences are broadly applicable.

\subsubsection{Elution factor}

We define $y_{\mathrm{c}}$ as the lowest point, and calculate it with the following equation (Table 2):

$$
y_{\mathrm{c}}=y_{\mathrm{o}}+A /(w \sqrt{\pi / 2}) \text {. }
$$

It has been previously shown that $50 \%-80 \%$ of the snowpack solute load is carried away by the earliest $20 \%-30 \%$ of the meltwater (Johannessen and Henriksen, 1978). In order to measure the ion loss rate, we determined an "Elution Factor" (e) calculated by the following equation (revised from Moore et al., 2005).

$$
e=1-\exp \left(\overline{\ln y_{\mathrm{o}}}-\overline{\ln y_{\mathrm{c}}}\right) .
$$

The results suggest that more than half of the snowpack ions were leached out of the snowpacks after the wet season (Table 3). Similar calculations from Arctic Snowpack at Lomonosovfonna, Svalbard (Moore et al., 2005) are much lower than the factors determined here. The high " $e$ " values of mineral elements $\mathrm{SO}_{4}{ }^{2-}$, $\mathrm{Ca}^{2+}$ and $\mathrm{Na}^{+}$show that these elements are mostly leached out of snow by meltwater. As previously determined, $\mathrm{Mg}^{2+}$ as the most stable ionic species in the snowpacks has an "e" value of 0.43 . An interpretation is that $\mathrm{Mg}^{2+}$ is adhered to the surface of insoluble dust particles. Therefore, it is less susceptible to leaching during elution compared with the other cation species that are located at ice-grain boundaries.

Table 3 Elution Factor (e) for ionic species

\begin{tabular}{cccccccccc}
\hline Ion & $\mathrm{Cl}^{-}$ & $\mathrm{SO}_{4}{ }^{2-}$ & $\mathrm{NO}_{3}^{-}$ & $\mathrm{Na}^{+}$ & $\mathrm{NH}_{4}^{+}$ & $\mathrm{K}^{+}$ & $\mathrm{Mg}^{2+}$ & $\mathrm{Ca}^{2+}$ & Source \\
\hline \multirow{2}{*}{$e$} & 0.60 & 0.84 & 0.76 & 0.70 & 0.56 & 0.61 & 0.43 & 0.74 & This study \\
& 0.31 & 0.43 & 0.47 & 0.28 & 0.28 & 0.35 & 0.27 & 0.37 & Moore et al. (2005) \\
\hline
\end{tabular}




\subsection{Variation of ionic concentrations in dry sea- sons}

In dry seasons, total ionic concentrations fluctuated slightly (Fig. 4). The concentration values ranged between 1,157-1,814, 2,080-3,083 and 1,567-2,512 $\mu \mathrm{g} / \mathrm{L}$ during the three dry seasons respectively. The intra-season differences of around $1,000 \mu \mathrm{g} / \mathrm{L}$ is less than the values in the wet seasons (about 3,000 $\mu \mathrm{g} / \mathrm{L}$ ). We found higher ion concentrations in the dry season of October 2004-April 2005 compared with the other two dry seasons. The precipitation amounts during the first dry season (October 2003-April 2004), the second dry season (October 2004-April 2005) and the third dry season (October 2005-April 2006) were 28 $\mathrm{mm}, 35.6 \mathrm{~mm}$ and $74.2 \mathrm{~mm}$, respectively; meanwhile, the daily average temperatures were in average $-15.9^{\circ} \mathrm{C},-15.4^{\circ} \mathrm{C}$ and $-16.3^{\circ} \mathrm{C}$, respectively. Neither the air temperature nor precipitation amount during the second dry season was significantly different from that of the other seasons.
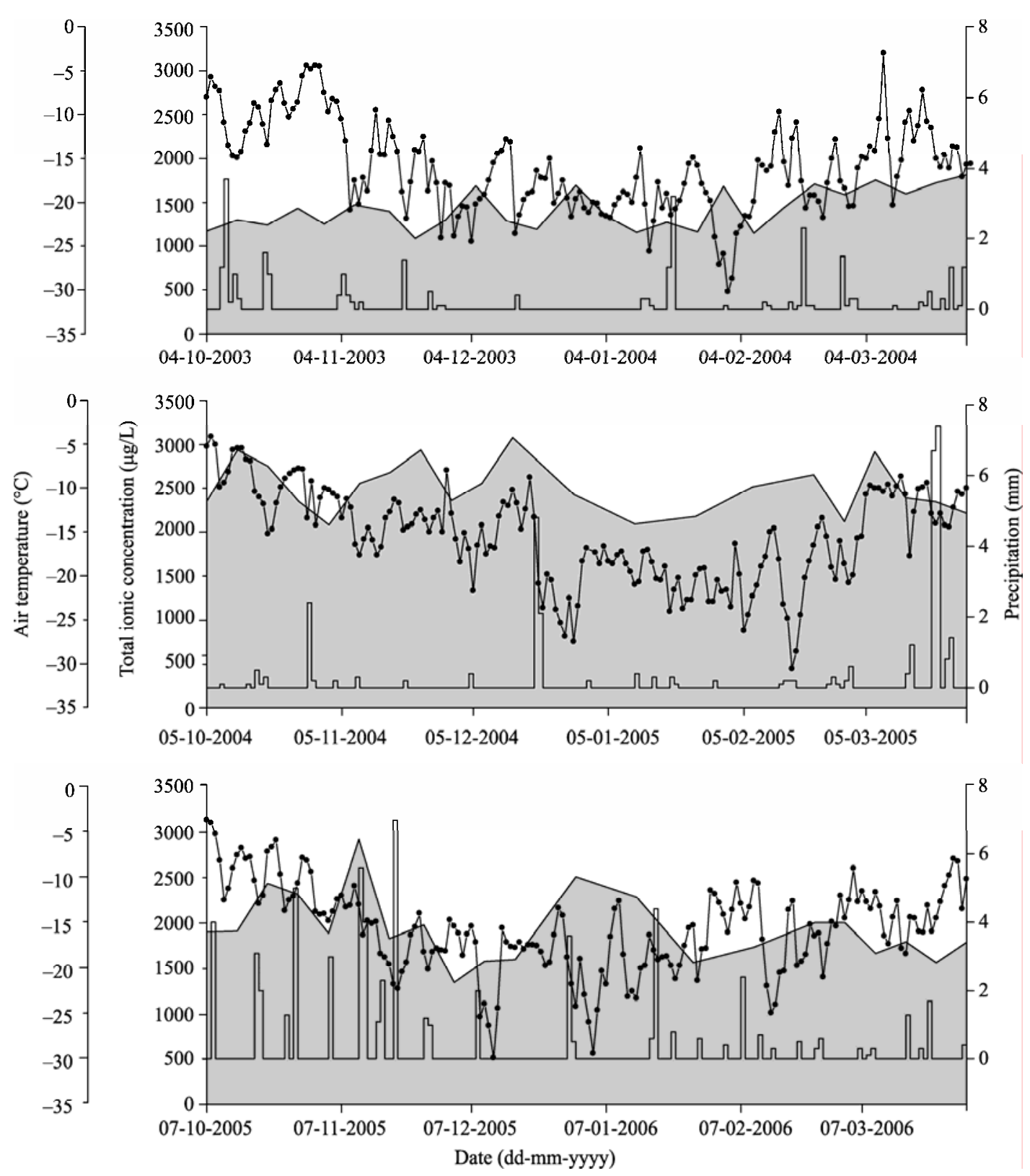

Fig. 4 Total ionic concentrations in the snowpacks, precipitations and air temperatures during the dry seasons of 2003-2006. The area figures are total ionic concentrations, step lines are precipitations and dot lines are daily average temperatures. 
The temperature during this period ranged between $-30.5^{\circ} \mathrm{C}$ and $-4.4^{\circ} \mathrm{C}$. This low temperature excludes any possibility of ion elution from melting. Thus, the reasons for the concentration fluctuation in the dry seasons are mainly attributed to the dry depositional or post-depositional processes. Higher rainfall frequency and amount of precipitation may cause the increase in ionic concentration (e.g. February 2004-March 2004 and October 2005-November 2005) (Fig. 4). However, similar increases in the total concentrations were also observed with very little precipitation (e.g. October 2003-December 2003). In addition, periods with strong precipitation events (e.g. at the end of March 2005) did not correspond to low concentrations. Therefore, precipitation is not the most influential factor for chemical components during the dry seasons.
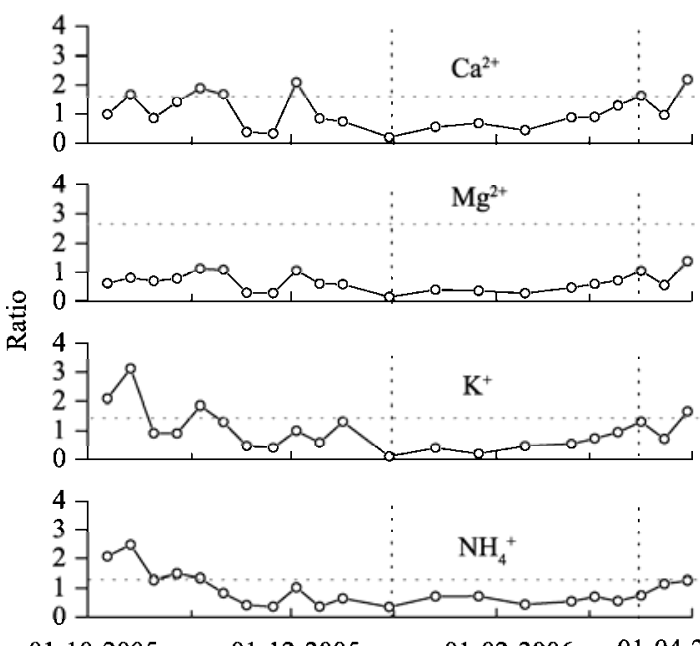

01-10-2005 01-12-2005
In order to demonstrate the variations of major ions, Fig. 5 presents the ratios of ionic concentrations in the surface snow to those in the snowpacks during the dry season of October 2005-March 2006. At the beginning stage of the ion record, the ionic concentrations in the surface snow reflect atmospheric deposition. Ions in the surface snow are mainly from dry deposition, precipitation and snowdrift. Ions in the snowpacks result from atmospheric deposition and post-depositional processes. The ratios of ionic concentrations between the surface snow and the snowpacks result from the total history of the snowpacks after deposition. $\mathrm{Mg}^{2+}$ and $\mathrm{Ca}^{2+}$ ratios display identical temporal variations in the dry season; similar variations are observed between $\mathrm{NH}_{4}{ }^{+}, \mathrm{SO}_{4}{ }^{2-}$ and $\mathrm{NO}_{3}{ }^{-}$, and between $\mathrm{Cl}^{-}$and $\mathrm{Na}^{+}$. The results suggest similarities in sources and depositional and/or post-depositional processes.
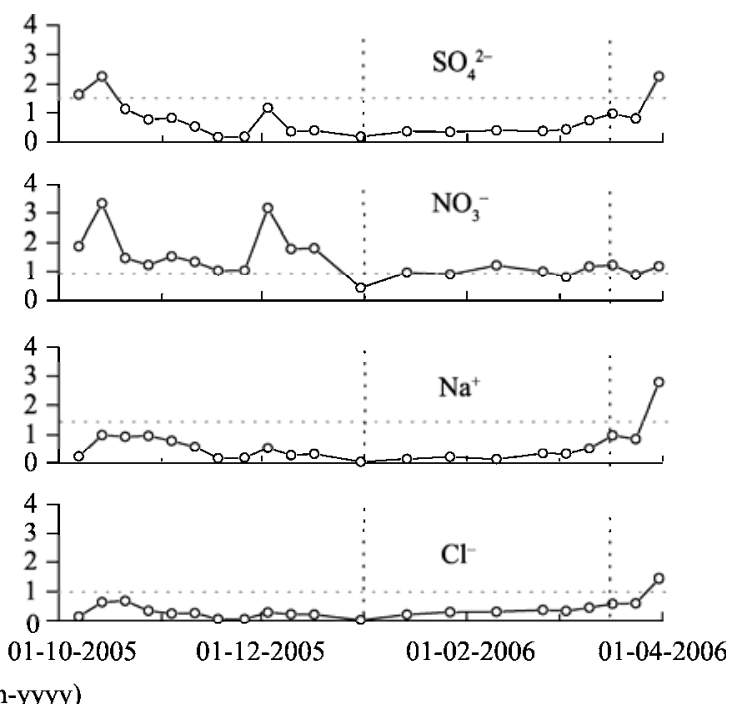

Fig. 5 The ratios of ionic concentrations in the surface snow to those in the snowpacks during the dry season of October 2005-March 2006. The two vertical dot lines divide the dry season into there periods. The horizontal dot lines stand for the ratio of 1.

For a detailed analysis, this dry season was further subdivided into three periods according to common variability, as shown in Fig. 5: October 2005-December 2005, January 2006-February 2006 and March 2006.

In the period of October 2005-December 2005, the total precipitation amounts reached $60.4 \mathrm{~mm}$. The ratio values of $\mathrm{Mg}^{2+}$ and $\mathrm{Ca}^{2+}$ exhibited similar variability characterized by intense fluctuations. This variability was probably the result of $\mathrm{Mg}^{2+}-$ and $\mathrm{Ca}^{2+}$-enriched terrestrial aerosols in the precipitation. During this time most of the surface to snowpack ratios for $\mathrm{Mg}^{2+}$ were less than 1 , indicating that the concentrations in the surface snow are lower than those in the snowpacks. This phenomenon suggests that $\mathrm{Mg}^{2+}$ was concentrated in the snowpacks by summer melting. The ratio records of $\mathrm{K}^{+}, \mathrm{NH}_{4}{ }^{+}, \mathrm{SO}_{4}{ }^{2-}$ and $\mathrm{NO}_{3}{ }^{-}$fluctuated with a declining trend. This variability suggests that the frequent precipitation also deposited these ions to the surface of the glacier (Fig. 4). $\mathrm{NO}_{3}{ }^{-}$was concen- 
trated in the surface snow during the period. This may be due to higher concentrations of $\mathrm{NO}_{3}{ }^{-}$in the precipitation or snowdrift scavenging of aerosols (Wolff et al., 1998). There are no obvious changes for $\mathrm{Cl}^{-}$and $\mathrm{Na}^{+}$, which implies little aerosol variability.

In the period of January 2006-February 2006, the impact of precipitation $(10.7 \mathrm{~mm}$ in total) on surface snow chemistry was trivial. Measurements from drifting snow near the sample site show that the net accumulation at this site was positive during the period even though the amount of precipitation was small. Therefore, the dry deposition, drifting snow and sublimation are possible contributors to the ionic variability. During this period, the fluctuations of the ratio curves for all ionic species are gentle, which implied that ionic concentrations in the surface snow and the snowpacks are very stable. Tiny differences among the ionic species may reflect the differences of post-depositional effects on different species. For example, $\mathrm{NO}_{3}{ }^{-}$was still able to concentrate in the surface snow with relatively high ratios. Ionic concentrations in the surface snow were less than those in the snowpacks, which suggests that as a whole post-depositional process slightly increased ionic concentrations.

In March 2006, the precipitation was small $(5.3 \mathrm{~mm}$ in total). However, the ionic concentrations in the surface snow rapidly exceeded those in the snowpacks. The increase could be explained by an increase in dust from Asian dust storms that are common during this time of year (Gao et al., 1992; Wake et al., 1994; You and Dong, 2011). Both the dust storms and precipitation are likely sources of the concentrated impurities in the glacier snow, as reflected by the increase of mineral species, especially for $\mathrm{Mg}^{2+}, \mathrm{Ca}^{2+}, \mathrm{SO}_{4}{ }^{2-}$ and $\mathrm{Na}^{+}$.

\section{Conclusions}

A detailed analysis was conducted on the transport of chemical components in homogeneous snowpacks on Urumuqi Glacier No. 1. The study found that the snowpacks, and therefore the glacial ice, incorporate a complex depositional and post-depositional history. Principle Component Analysis and eigenvector comparison revealed variations in snowpack ion mobility and associations from depositional and post-depositional processes during dry and wet seasons. In the dry season, snowpack ionic chemistry displayed independent variation among the ionic species. In contrast, during the wet season, ions became associated with meltwater leaching and transport. The elution characteristics of ions were investigated and the elution sequence for the snowpacks determined from temporal variations in the snowpacks. Variations in the ion elution sequence found by the study may provide an important tool for interpreting ion separation in the ice core records and for understanding alpine ice core records with respect to post-depositional processes and enhanced concentrations of chemical species found in the most recent sections of ice.

\section{Acknowledgements}

This work was supported by the National Natural Science Foundation of China (41261017). The authors sincerely thank all the contributors for obtaining field monitoring data.

\section{References}

Aizen E M, Aizen V B, Melack J M, et al. 2001. Precipitation and atmospheric circulation patterns at mid-latitudes of Asia. International Journal of Climatology, 21(5): 535-556.

Bales R C, Davis R E, Stanley D A. 1989. Ion elution through shallow homogeneous snow. Water Resources Research, 25(8): 1869-1877.

Bernhardt M, Schulz K, Liston G E, et al. 2012. The influence of lateral snow redistribution processes on snow melt and sublimation in alpine regions. Journal of Hydrology, 424: 196-206.

Brimblecombe P. 1985. Relocation and preferential elution of acidic solute through the snowpack of a small, remote, high-altitude Scottish catchment. Annals of Glaciology, 7: 141-147.

Brimblecombe P, Clegg S L, Davies T D, et al. 1987. Observations of the preferential loss of major ions from melting snow and laboratory ice. Water Research, 21(10): 1279-1286.

Davis R E. 1991. Links between snowpack chemistry and snowpacks physics. In: Processes of Chemical Change in Snowpacks. Berlin: Springer Berlin Heidelberg, 115-138.

Eichler A, Schwikowski M, Gäggeler H W. 2001. Meltwater-induced relocation of chemical species in Alpine firn. Tellus, 53B: 192-203.

Gao Y, Arimoto R, Zhou M Y, et al. 1992. Relationships between the dust concentrations over eastern Asia and the remote North Pacific. Journal of Geophysical Research, 97(D9): 9867-9872.

Ginot P, Kull C, Schwikowski M. 2001. Effects of post-depositional processes on snow composition of a subtropical glacier (Cerrado Tapado, Chilean Andes). Journal of Geophysical Research, 106(23): 32375-32386.

Goto-Azuma K, Nakawo M, Han J. 1994. Melt-induced relocation of 
ions in glaciers and in a seasonal snowpack. IAHS Publication, 223(4): 287-297.

Harrington R, Bales R C, Wagnon P. 1996. Variability of meltwater and solute fluxes from homogenous melting snow at the laboratory scale. Hydrological Processes, 10: 945-953.

Harrington R, Bales R C. 1998. Modeling ionic solute transport in melting snow. Water Resource Research, 34(7): 1727- 1736.

Hewitt A D, Cragin J H, Colbeck S C. 1989. Does snow have ion chromatographic properties? In: Proceedings of the $46^{\text {th }}$ Annual Eastern Snow Conference. Quebec: 165-171.

Hou S G, Qin D H. 2002. The effect of postdepositional process on the chemical profiles of snow pits in the percolation zone. Cold Regions Science and Technology, 34(2): 111-116.

Iizuka Y, Igarashi M, Kamiyama K, et al. 2002. Ratios of $\mathrm{Mg}^{2+} / \mathrm{Na}^{+}$in snowpack and an ice core at Austfonna ice cap, Svalbard, as an indicator of seasonal melting. Journal of Glaciology, 48(162): 452-460.

Johannessen M, Henriksen A. 1978. Chemistry of snow meltwater: changes in concentration during melting. Water Resources Research, 14(4): 615-619.

Lee J, Nez V E, Feng X H, et al. 2008a. A study of solute redistribution and transport in seasonal snowpack using natural and artificial tracers. Journal of Hydrology, 357(3): 243-254.

Lee J, Feng X H, Posmentier E S, et al. 2008b. Modeling of solute transport in snow using conservative tracers and artificial rain-on-snow experiments. Water Resources Research, 44(2): 1-12.

Li X Y, Li Z Q, Ding Y J, et al. 2007. Seasonal variations of $\mathrm{pH}$ and electrical conductivity in a snow-firn pack on Glacier No. 1, eastern Tianshan, China. Cold Regions Science and Technology, 48(1): 55-63.

Li Z Q, Han T D, Jin Z F, et al. 2003. A summary of 40-year observed variation facts of climate and Glacier No. 1 at headwater of Urumqi River, Tianshan, China. Journal of Glaciology and Geocryology, 25(2): 117-121. (in Chinese)

Li Z Q, Edwards R, Mosley-Thompson E, et al. 2006. Seasonal variability of ionic concentrations in surface snow and elution processes in snow-firn packs at the PGPI site on Urumqi glacier No. 1, eastern Tien Shan, China. Annals of Glaciology, 43(1): 250-256.

Luo H Z. 1983. Hydro chemical features of the Glacier No.1 in the source region of Urumqi River, Tianshan. Journal of Glaciology and Geocryology, 5(2): 55-64. (in Chinese)

Meyer T, Wania F. 2011. Modeling the elution of organic chemicals from a melting homogeneous snow pack. Water Research, 45(12): $3627-3637$.

Moore J C, Grinsted A, Kekonen T, et al. 2005. Separation of melting and environmental signals in an ice core with seasonal melt. Geophysical Research Letters, 32(10), doi: 10.1029/2005GL023039.

Moore J C, Grinsted A. 2009. Ion fractionation and percolation in ice cores with seasonal melting. Low Temperature Science, 68: 287-298.

Schotterer U, Ginot W S P. 2004. The influence of post-depositional effects on ice core studies: examples from the Alps, Andes, and Altai. Developments in Paleoenvironmental Research, 9: 39-59.

Sigg A, Neftel A. 1991. Evidence for a 50 percent increase in $\mathrm{H}_{2} \mathrm{O}_{2}$ over the past 200 years from a Greenland ice core. Nature, 351: 557-559.

Tsiouris T, Vincent C E, Davies T D, et al. 1985. The elution of ions through field and laboratory snowpacks. Annals of Glaciology, 7(21): 501-507.

Tranter M. 1991.Controls on the composition of snowmelt. Seasonal Snowpacks (NATO ASI Series), 28: 241-271.

Tranter M, Tsiouris S, Davies T D, et al. 1992. A laboratory investigation of the leaching of solute from snowpack by rainfall. Hydrological Processes, 6(2): 169-178.

Wagnon P, Delmas R J, Legrand M. 1999. Loss of volatile acid species from upper firn layers at Vostok, Antarctica. Journal of Geophysical Research, 104(D3): 3423-3431.

Wake C P, Mayewski P A, Li Z Q, et al. 1994. Modern eolian dust deposition in Central Asia. Tellus, 46B(3): 220-233.

Wang D, Zhang P. 1985. On the valley climate of Urumqi River in the Tianshan Mountains. Journal of Glaciology and Geocryology, 7(3): 239-248. (in Chinese)

Wang F T, Li Z Q, You X N, et al. 2006. Seasonal evolution of aerosol stratigraphy in Urumqi glacier No. 1 percolation zone, eastern Tien Shan, China. Annals of Glaciology, 43: 245-249.

Williams M W, Tonnessen K A, Melack J M, et al. 1991. Sources and spatial variation of the chemical composition of snow in the Tien Shan, China. Annals of Glaciology, 16: 25-32.

Wolff E W, Hall J S, Mulvaney R, et al. 1998. Relationship between chemistry of air, fresh snow and firn cores for aerosol species in coastal Antarctica. Journal of Geophysical Research, 103(D9): 11057-11070.

You X N, Li Z Q, Wang F T. 2005. Study on time scale of snow-ice transformation through snow layer tracing method-take Glacier No.1 at the headwaters of Urumqi River as an example. Journal of Glaciology and Geocryology, 27(6): 853-860. (in Chinese)

You X N, Dong Z W. 2011. Deposition process of dust microparticles from aerosol to snow-firn pack on Glacier No. 1 in eastern Tianshan Mountains, China. Journal of Earth Science, 22(4): 460-469.

You X N, Li Z Q. 2012. Study on deposition characteristics of insoluble microparticles and $\mathrm{Mg}^{2+}$ concentration in snow cover and their correlation. Arid Zone Research, 29(1): 143-147. (in Chinese)

Zhao Z P, Li Z Q. 2004. Determination of soluble ions in atmospheric aerosol by ion chromatography. Modern Scientific Instruments, (5): 46-49. (in Chinese)

Zhao Z P, Li Z Q, Edwards R, et al. 2006. Atmosphere-to-snow-to-fsfirn transfer of $\mathrm{NO}_{3}{ }^{-}$on Glacier No.1, eastern Tianshan, China. Annals of Glaciology, 43(1): 239-244. 